\title{
The nolL Gene from Rhizobium etli Determines Nodulation Efficiency by Mediating the Acetylation of the Fucosyl Residue in the Nodulation Factor
}

\author{
Adriana Corvera, ${ }^{1}$ Danielle Promé, ${ }^{2}$ Jean-Claude Promé, ${ }^{2}$ Esperanza Martínez-Romero, ${ }^{1}$ and \\ David Romero ${ }^{1}$ \\ ${ }^{1}$ Programa de Biología Molecular de Plásmidos Bacterianos, Centro de Investigación sobre Fijación \\ de Nitrógeno, Universidad Nacional Autónoma de México, Ap. Postal 565-A, Cuernavaca, Morelos, \\ 62271, México; ${ }^{2}$ Institut de Pharmacologie et Biologie Structurale, Spectrometrie de Masse et Signaux \\ Biologiques, Centre National de la Recherche Scientifique, 205 Route de Narbonne 31077, Toulouse \\ Cedex, France \\ Accepted 3 December 1998.
}

The nodulation factors (Nod factors) of Rhizobium etli and $R$. loti carry a 4-O-acetyl-L-fucosyl group at the reducing end. It has been claimed, based on sequence analysis, that NolL from $R$. loti participates in the 4-O-acetylation of the fucosyl residue of the Nod factors, as an acetyl-transferase (D. B. Scott, C. A. Young, J. M. Collins-Emerson, E. A. Terzaghi, E. S. Rockman, P. A. Lewis, and C. E. Pankhurst. Mol. Plant-Microbe Interact. 9:187-197, 1996). Further support for this hypothesis was obtained by studying the production of Nod factors in an R. etli nolL::Km mutant. Chromatographic and mass spectrometry analysis of the Nod factors produced by this strain showed that they lack the acetyl-fucosyl substituent, having a fucosyl group instead. Acetyl-fucosylation was restored upon complementation with a wild-type nolL gene. These results indicate that the nolL gene determines 4-O-acetylation of the fucosyl residue in Nod factors. Analysis of the predicted NolL polypeptide suggests a transmembranal location and that it belongs to the family of integral membrane transacylases (J. M. Slauch, A. A. Lee, M. J. Mahan, and J. J. Mekalanos. J. Bacteriol. 178:5904-5909, 1996). NolL from $\boldsymbol{R}$. loti was also proposed to function as a transporter; our results show that NolL does not determine a differential secretion of Nod factors from the cell. We also performed plant assays that indicate that acetylation of the fucose conditions efficient nodulation by $R$. etli of some Phaseolus vulgaris cultivars, as well as of an alternate host (Vigna umbellata).

Symbiotic relationships between bacteria of the genera $\mathrm{Al}$ lorhizobium, Azorhizobium, Bradyrhizobium, Mesorhizobium, Rhizobium, and Sinorhizobium (collectively called Rhizobia) with leguminous plants are established in response to a chemical communication between the plant and the bacterium.

Corresponding author: David Romero; Telephone: (52 73) 1758 67; Fax: (52 73) 1755 81; E-mail: dromero@ cifn.unam.mx

Nucleotide and/or amino acid sequence data are to be found at the GenBank data base as accession number AF047684.
Leguminous plants secrete, among other compounds, flavonoid and iso-flavonoid molecules that act as specific activators for the biosynthesis in the bacteria of specific signal compounds, the so-called nodulation factors (Nod factors) (Fisher and Long 1992; Spaink 1995; Dénarié et al. 1996). These Nod factors can also activate several plant genes and unravel a series of responses and cellular changes that determine the development of specialized structures called nodules (Relić et al. 1993, 1994; Mylona et al. 1995). Inside the nodule, the bacteria are able to change their metabolism to fix nitrogen (Sprent and Sprent 1990; Mylona et al. 1995).

Although many studies have been done on the genetic elements involved in the synthesis and secretion of rhizobial Nod factors, information is still lacking on several of these determinants (for recent reviews see Carlson et al. 1994; Schultze et al. 1994; Spaink 1995; Van Rhijn and Vanderleyden 1995; Dénarié et al. 1996; Pueppke 1996). New species and specific strains secrete different chitolipooligosaccharidic molecules as Nod factors. Common elements between them are the chemical nature of the core molecules and that they are always $\mathrm{N}$ acylated on the nonreducing end (even though the length of the core and the acyl chain is not the same for different Nod factors). All these molecules have several substituent groups localized mainly on the reducing and nonreducing end glucosamines. The exact function of these substituents is not yet clear, although it has been hypothesized that they might protect the molecule against plant chitinases (Staehelin et al. 1994) and/or confer specificity for binding to plant receptors (reviewed in Dénarié et al. 1994; Bladergroen and Spaink 1998).

Rhizobium etli CE3 synthesizes and secretes chitopentamers of $\mathrm{N}$-acetyl-D-glucosamine that are $\mathrm{N}$-substituted at the nonreducing end with cis-vaccenic or stearic acid and a methyl group; they may or may not be carbamoylated on $\mathrm{C} 4$. At the reducing end, these molecules are 4-O-acetyl-fucosylated on C6 (Cárdenas et al. 1995; Poupot et al. 1995).

An initial step in the understanding of the biosynthesis of Nod factor molecules is the characterization of specific genes and the construction of mutant strains to study their phenotypes. Here, we describe the identification and characterization of nolL, a gene involved in 4-O-acetylation of the fucosyl 
residue of the nodulation factor of Rhizobium etli. We establish that the predicted polypeptide may be a transmembranal acetyl-transferase, part of a family of integral membrane trans-acylases (IMTs; Slauch et al. 1996). We also show that a mutation in this gene has a quantitative effect on the total nodule number that can be formed by the strain on different Phaseolus vulgaris cultivars and on Vigna umbellata.

\section{RESULTS}

\section{Production of nodulation factors is altered in a strain} carrying a large deletion on the pSym.

We studied the nodulation factors produced and secreted by some strains of $R$. etli in the presence of genistein as an inducer. Compounds labeled with ${ }^{14} \mathrm{C}$-glucosamine were analyzed qualitatively by direct-phase thin-layer chromatography (TLC), as described in Materials and Methods. Wild-type strain CE3 and strain CFNX250, containing a deleted pSym (pGM1, Fig. 1; see also Table 1), have different Nod factor profiles (Fig. 2A, arrows); it can be seen (Fig. 2A) that a fastmigrating compound is no longer produced by strain CFNX250. In order to identify the genetic determinants necessary for wild-type production of nodulation factors, we made sequential complementation assays of strain CFNX250 with plasmids pDEL270, pDEL217, cGD45, and cGD7 (Fig. 1).

Plasmid pDEL270, but not plasmid pDEL217, was able to complement strain CFNX250 for wild-type Nod factor pro- duction (Table 2), as evaluated on TLC plates (data not shown). Cosmid clones cGD45 and cGD7 contain the information present in pDEL270 but absent in pDEL217 (Fig. 1); thus, they were used to delimit the genetic region proficient for complementation. Only cGD7 was able to complement CFNX250 for the wild-type phenotype (Table 2; and data not shown). Further subcloning of the cGD7 cosmid clone with restriction enzyme BamHI led us to the identification of a 3.8$\mathrm{kb}$ fragment-band 81 from the pSym CE3 (Girard et al. 1991), cloned in plasmid pRK7813 (Jones and Gutterson 1987), giving rise to plasmid pACP1 - that is able to restore wild-type production of Nod factors on strain CFNX250 (Figs. 1 and 2A).

\section{Altered production of nodulation factors in strain CFNX250 is only due to the absence of the nolL gene.}

Sequence analysis of the complementing fragment revealed the presence of an open reading frame with a high similarity to the previously described nolL gene (see below). To ascertain the participation of this gene in Nod factor production, a $\mathrm{Km}$-interposon was introduced at the unique NheI site of the nolL gene (at $456 \mathrm{bp}$ from the stop codon and at $526 \mathrm{bp}$ from the end of the subclone), thus generating plasmid pACP3. Introduction of the $\mathrm{Km}$ cassette might result in the production of a shortened polypeptide (240 amino acids [aa] long). Wildtype phenotype for Nod factor production can be restored in strain CFNX250 with pACP1 (strain CFNX287; Fig. 2A) but

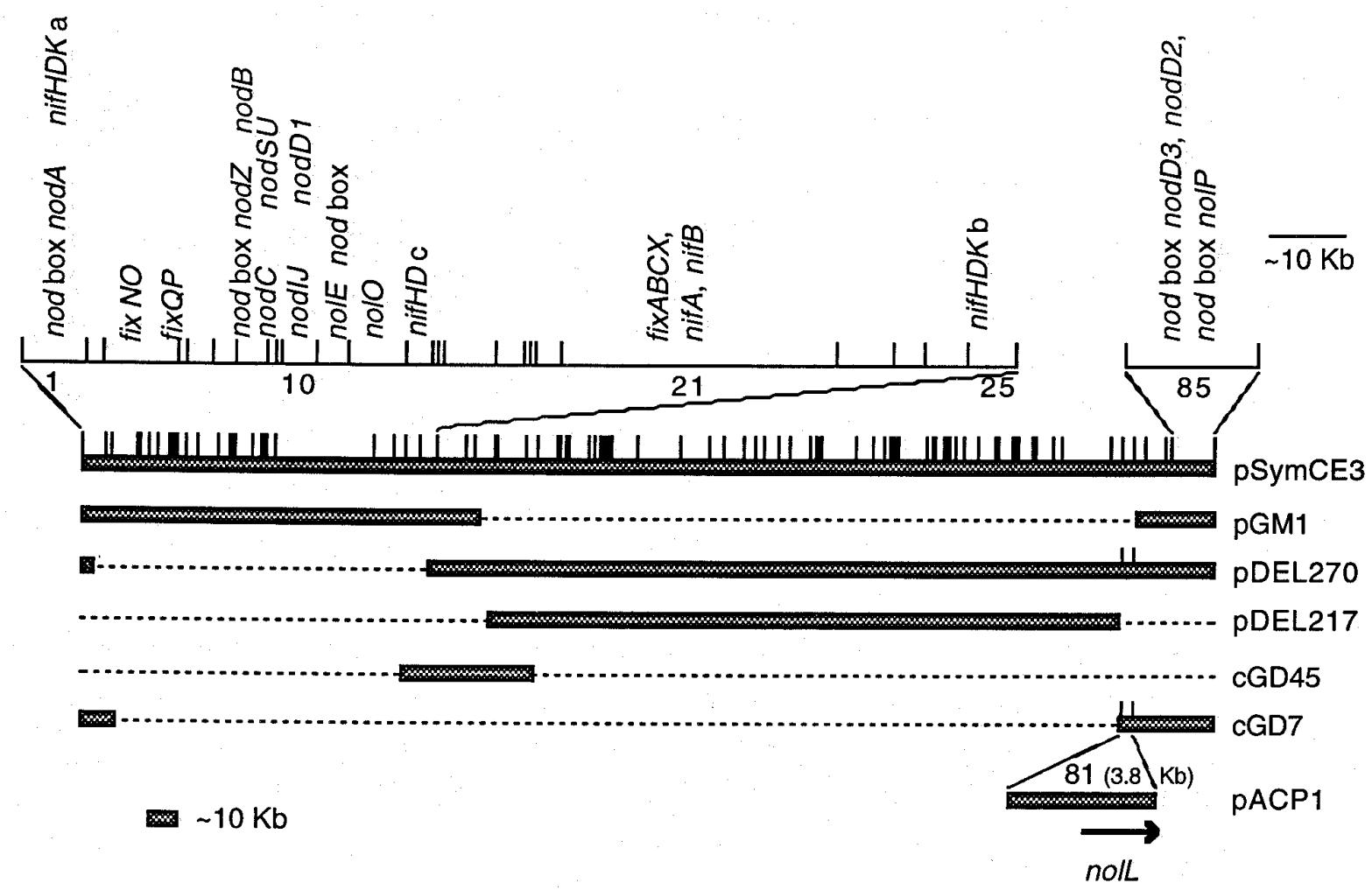

Fig. 1. Linear physical map of the symbiotic plasmid of Rhizobium etli CE3 (pSym CE3), showing BamHI restriction sites (vertical lines; Girard et al. 1991). Enlarged zones show the aproximate localization of the identified nod and nol genes and some of the nif and fix genes (numbers below the amplified maps indicate original number of some of the BamHI bands; Girard et al. 1991, given only as reference). Stripped boxes below the map of pSym CE3 indicate conserved segments in pGM1, and in those plasmids used for complementation of strain CFNX250 for wild-type profile of nodulation factors. BamHI sites indicated in the maps of pDEL270 and cGD7 indicate that these are the two clones that conserve band 81. Broken lines indicate sequences absent in the complementing clones. These maps were drawn after information compiled from Girard et al. (1991, 1996), Villalobos et al. (1994), and G. Dávila and P. Bustos, unpublished. 
not in the presence of pACP3 (strain CFNX288; Fig. 2A). Further fragmentation of the $3.8-\mathrm{kb}$ BamHI band showed that a 2.8-kb EcoRI fragment (which, according to our prediction, results in a protein lacking only $44 \mathrm{aa}$ ) is not able to restore the wild-type production of Nod factors on strain CFNX250 (data not shown). These data demonstrate that the altered production of nodulation factors in CFNX250 is only due to the absence of the nolL gene in this strain.

To further verify the participation of nolL in Nod factor production in an otherwise wild-type background, the nolL:: Km allele was introduced by homogenotization onto a wild-type pSym. The fidelity of the desired marker exchange was verified by Southern hybridization with nolL- and vectorspecific probes (data not shown). The nodulation factors produced by this mutant strain (CFNX289) show the same pattern on TLC plates as those from strain CFNX250 (Fig. 2A). Wildtype phenotype can be restored when CFNX289 is complemented with pACP1, but not in the presence of pACP3 (not shown). Complementation assays with a $1.8-\mathrm{kb}$ fragment of band 81 from the pSym CE3 (plasmid pACP5) that includes the whole nolL gene with its putative nod-box showed that it is able to complement both CFNX250 (strain CFNX296; Fig. 2A) and CFNX289 (strain CFNX295; Fig. 2A) for wild-type production of Nod factors.

Table 1. Strains and plasmids used in this study

\begin{tabular}{|c|c|c|}
\hline Strain or plasmid & Relevant characteristics & Reference \\
\hline \multicolumn{3}{|l|}{ Rhizobium etli } \\
\hline CFN42 & $\begin{array}{l}\text { Species type strain; carries six endogenous plasmids named a to } \mathrm{f} \text {; pd is the symbiotic } \\
\text { plasmid (pSym) }\end{array}$ & Quinto et al. 1982; Segovia et al. 1993 \\
\hline CE3 & $\mathrm{Sm}^{\mathrm{r}}$ derivative of CFN42. & Noel et al. 1984 \\
\hline CFNX89 & CE3 derivative cured of pSym & Brom et al. 1992 \\
\hline CFNX250 & CE3 derivative, carrying a $220-\mathrm{kb}$ deletion in the pSym (pGM1) & D. Romero, unpublished. \\
\hline CFNX252 & CFNX250/pDEL270 & A. Eparvier and D. Romero, unpublished \\
\hline CFNX254 & CFNX250/pDEL217 & A. Eparvier and D. Romero, unpublished \\
\hline CFNX273 & CFNX250/cGD7 & A. Eparvier and D. Romero, unpublished \\
\hline CFNX278 & CFNX250/cGD45 & A. Eparvier and D. Romero, unpublished \\
\hline CFNX287 & CFNX250 / pACP1 & This study \\
\hline CFNX288 & CFNX250/ pACP3 & This study \\
\hline CFNX289 & CE3 derivative, nolL::Km & This study \\
\hline CFNX290 & CFNX289 derivative carrying pACP1 & This study \\
\hline CFNX295 & CFNX289 derivative carrying pACP5 & This study \\
\hline CFNX296 & CFNX250 derivative carrying pACP5 & This study \\
\hline CFNX297 & CE3 derivative carrying pACP6 & This study \\
\hline CFNX298 & CE3 derivative carrying pBBMCS53 & This study \\
\hline CFNX299 & CFNX89 derivative carrying pACP6 & This study \\
\hline $\mathrm{CFN}-1$ & Wild-type strain isolated from Guanajuato, México & Piñero et al. 1988 \\
\hline BRA-5 & Wild-type strain isolated from Brazil & Piñero et al. 1988 \\
\hline TAL-182 & Wild-type strain isolated from Hawaii, U.S.A. & Piñero et al. 1988 \\
\hline VIKING-1 & Wild-type strain isolated from Belize & Piñero et al. 1988 \\
\hline NITRAGIN 8251 & Wild-type strain isolated from U.S.A. & Piñero et al. 1988 \\
\hline CIAT-894 & Wild-type strain isolated from Colombia & Piñero et al. 1988 \\
\hline CIAT-895 & Wild-type strain isolated from Colombia & Piñero et al. 1988 \\
\hline KIM 5 & Wild-type strain isolated from Kimberly, Idaho, U.S.A. & Josephson and Pepper 1984 \\
\hline $127 \mathrm{~K} 81-3$ & Wild-type strain isolated from North Dakota, U.S.A. & Weaver et al. 1990 \\
\hline \multicolumn{3}{|c|}{ 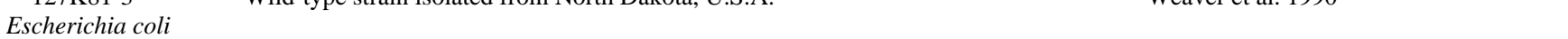 } \\
\hline DH5 $\alpha$ & Host for recombinant plasmids, $\mathrm{Nal}^{\mathrm{r}}$ & Sambrook et al. 1989 \\
\hline BW21038 & pir $^{+}$host for Ori R6K plasmids, $\mathrm{Cm}^{\mathrm{r}}$ & Metcalf et al. 1996 \\
\hline HB101 & Host for conjugation helper plasmid pRK2073 & Sambrook et al. 1989 \\
\hline \multicolumn{3}{|c|}{ 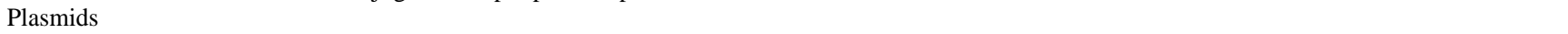 } \\
\hline pRK2073 & Conjugation helper plasmid & Better and Helinski 1983 \\
\hline pRK7813 & $\mathrm{Tc}^{\mathrm{r}}$ cloning vector & Jones and Gutterson 1987 \\
\hline pMOSBlueT & Cloning vector for polymerase chain reaction pro ducts & Amersham, Buckinghamshire, U.K. \\
\hline pWM91 & Ori R6K vector plasmid; carries the sacRB genes for positive selection & Metcalf et al. 1996 \\
\hline pBSL128 & Vector plasmid carrying a $\mathrm{Km}-\Omega$ element & Alexeyev et al. 1995 \\
\hline pBBR1MCS-5 & $\mathrm{Gm}^{\mathrm{r}}$ cloning vector & Kovach et al. 1995 \\
\hline pWM5 & Vector plasmid carrying a $\beta$-glucuronidase cassette & Metcalf and Wanner 1993 \\
\hline pBBMCS53 & pBBR1MCS-5 derivative carrying the promotorless gusA gene from pWM5 & L. Girard, unpublished \\
\hline pACP1 & BamHI band 81 from the pSym CE3 subcloned in pRK7813 & This study \\
\hline pACP3 & pACP1 with a Km cassette insertion (from pBSL128) & This study \\
\hline pACP4 & BamHI band 81 from the pSym CE3 with the Km cassette subcloned in pWM91 & This study \\
\hline pACP5 & $\begin{array}{l}\text { 1.8-kb fragment from band } 81 \text { from the pSym CE3 (including the nolL gene with its } \\
\text { putative nod-box) subcloned in pRK7813 }\end{array}$ & This study \\
\hline pACP6 & $\begin{array}{l}\text { 2.8-kb EcoRI fragment from band } 81 \text { from the pSym CE3, subcloned in pBBMCS53, } \\
\text { forward direction }\end{array}$ & This study \\
\hline cGD7 & Cosmid vector 7 from the cosmid collection & Girard et al. 1991 \\
\hline cGD45 & Cosmid vector 45 from the cosmid collection & Girard et al. 1991 \\
\hline pGM1 & $\begin{array}{l}\text { A pSym derivative containing } 170 \mathrm{~kb} \text { (the nod-nif region, bands } 82-27 \text { ), cointegrated } \\
\text { into pa. nifHa:: Km, Gm/Sp, Sm }\end{array}$ & D. Romero, unpublished \\
\hline pDEL270 & A type I deleted pSym derivative retaining from band 25 to 85 & Romero et al. 1995 \\
\hline pDEL217 & A type IV deleted pSym derivative retaining from band 28 to 80 & Romero et al. 1995 \\
\hline
\end{tabular}




\section{Mass spectrometry analysis of the compounds produced by mutant strains.}

To establish the chemical nature of the Nod factor component absent in strain CFNX250, strains CE3 and CFNX250 were grown in minimal medium in the presence of genistein. Butanol-extracted compounds from these cultures were purified by high-pressure liquid chromatography (HPLC) and then analyzed by liquid secondary ion mass spectrometry (LSIMS). Consistent with data from the literature (Cárdenas et al. 1995; Poupot et al. 1995), the spectrum of compounds produced by strain CE3 showed mainly two peaks at $\mathrm{m} / \mathrm{z} 1458.8$ and 1501.9 (Fig. 3A). The former corresponds to a protonated pentamer of glucosamine, $\mathrm{N}$-methylated and $\mathrm{N}$-vaccenoylated on one end, $\mathrm{N}$-acetylated on all other glucosamine residues and substituted by an acetylated fucosyl group. The latter bears an additional carbamoyl group. Examination of the fragmentation spectra (not shown) confirms that the carbamoyl group is at the nonreducing end, whereas the acetylfucosyl group is at the other end; we did not proceed further in a more precise localization of these substituents, since their localization has already been reported (Cárdenas et al. 1995; Poupot et al. 1995). The peak at $m / z 1416.7$ is the nonacetylated, noncarbamoylated species. Its carbamoylated analog should be at $m / z$ 1459.8, that is, superimposed with the M+1 peak of the isotopic distribution of the main component. Finally, the peak at $m / z 1432.6$ is an analog where the vaccenoyl group is replaced by a palmitoyl substituent, while the peak at $\mathrm{m} / \mathrm{z} 1480.8$ is the sodium attachment to the main component.

In contrast, extracts from strain CFNX250 exhibited two main ions at $m / z 1416.8$ and 1459.8 (Fig. 3B). These ions cor- respond to the same $\mathrm{M}+\mathrm{H}$ species as before but devoid of any $O$-acetyl group on the fucosyl moiety. These assignments were confirmed by an MS/MS experiment performed on each species, showing that the $42 \mathrm{U}$ mass shift down, compared with the main peaks seen in Figure $3 \mathrm{~A}$, was located on the reducing end (spectra not shown). Some of the scarcely represented ions in both LSIMS spectra are sodium and potassium adducts and the palmitoyl analog. These results clearly show that CFNX250 is not able to synthesize Nod factors with a 4$O$-acetyl substitution on the fucose. As we have already shown that the nolL gene is the only gene responsible for the altered production of Nod factors in strain CFNX250, it is clear that it is involved in acetylation.

Further evidence was obtained from an LSIMS analysis of strain CFNX289 (Fig. 3C). To avoid any elimination of Nod factors by a preliminary HPLC run, we made a spectrum from the crude extract, after forcing the formation of sodium ad-

Table 2. Plasmid content and Nod factor phenotype of wild-type CE3 and its derivatives

\begin{tabular}{lcc}
\hline Strain & Relevant plasmid content & $\begin{array}{c}\text { Nod factor bands } \\
\text { seen on TLC plates }\end{array}$ \\
\hline CE3 & pSymCE3 & $\mathrm{a}+\mathrm{b}$ \\
CFNX250 & pGM1 & $\mathrm{b}$ \\
CFNX252 & pGM1+pDEL270 & $\mathrm{a}+\mathrm{b}$ \\
CFNX254 & pGM1+pDEL217 & $\mathrm{b}$ \\
CFNX278 & pGM1+cGD45 & $\mathrm{b}$ \\
CFNX273 & pGM1+cGD7 & $\mathrm{a}+\mathrm{b}$ \\
CFNX287 & pGM1+pACP1 & $\mathrm{a}+\mathrm{b}$ \\
\hline
\end{tabular}

${ }^{\mathrm{z}}$ As defined in Figure 2. TLC $=$ thin-layer chromatography.
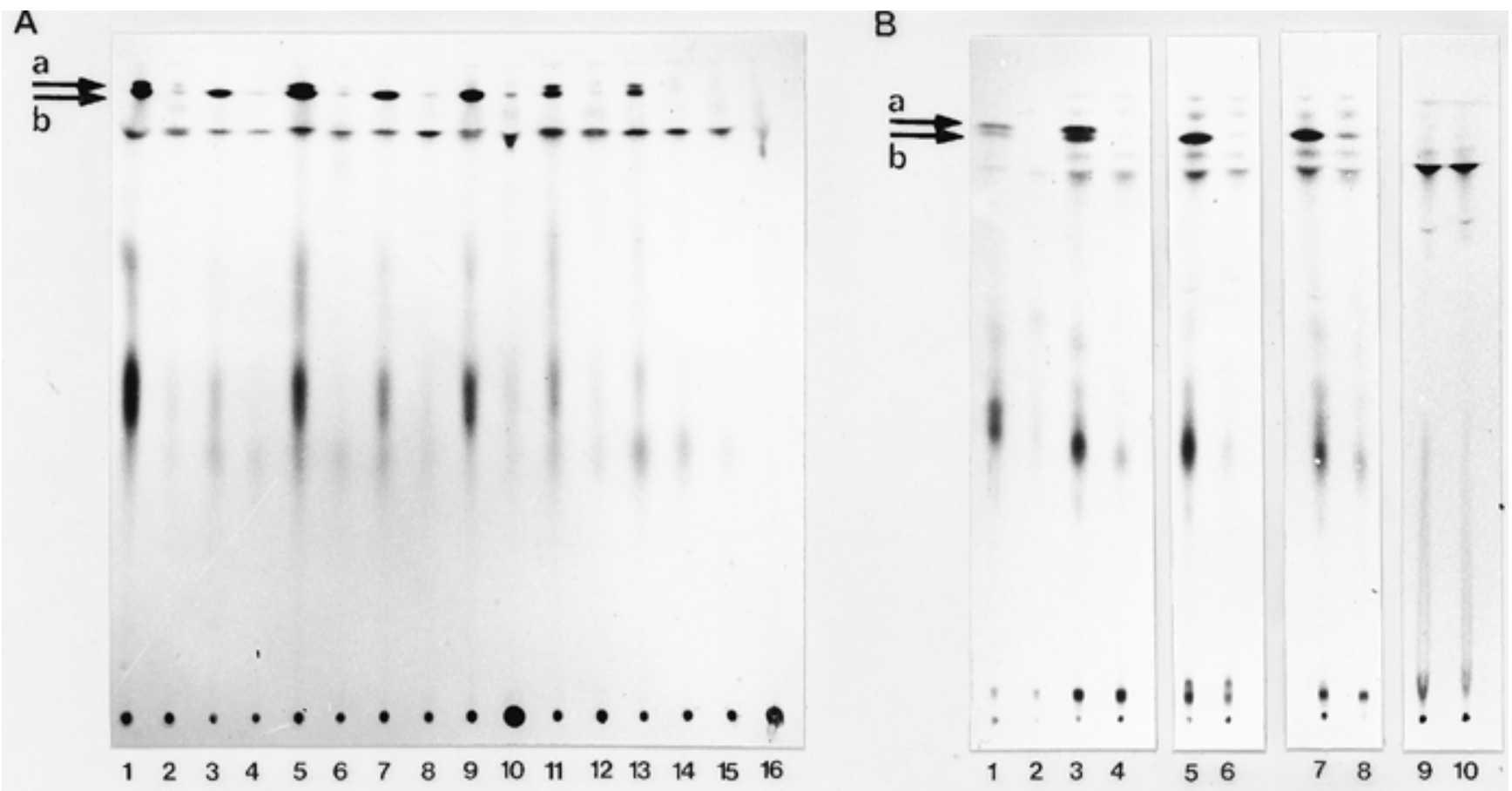

Fig. 2. Thin-layer chromatography (TLC) plates of nodulation factors (A and $\mathbf{B}$, lanes 1,2) secreted and (B) cell-extracted from CE3 and its derivatives. A, Lanes 1 and 2, strain CE3; lanes 3 and 4, CFNX250; lanes 5 and 6, CFNX287; lanes 7 and 8, CFNX288; lanes 9 and 10, CFNX289; lanes 11 and 12, CFNX295; lanes 13 and 14, CFNX296; lanes 15 and 16, CFNX89. B, Lanes 1 and 2, CE3 (secreted); lanes 3 and 4, CE3; lanes 5 and 6, CFNX289, lanes 7 and 8, CFNX250; lanes 9 and 10, CFNX89. Odd lane numbers: Compounds from cultures induced with genistein. Even lane numbers: compounds from uninduced cultures. Arrows indicate most abundant Nod factors produced by strain CE3: "a" produced by nolL+ strains; "b" produced by both nolL+ and nolL- strains. 
ducts, thus inducing a $22 \mathrm{U}$ mass shift, compared with the protonated species. This was necessary as the presence of several inorganic salts in the crude extract induced the formation of a wide variety of cation-adducted molecules. Similar to the spectrum from CFNX250's compounds, two major peaks at $\mathrm{m} / z, 1438.6$ and 1481.5 were seen for the Nod factors produced by strain CFNX289 (Fig. 3C). These ions are the sodium adducts of the same species seen in Figure 3B. Other peaks corre- sponded to the potassium adducts. Thus, the nolL gene is involved in acetylation of the fucosyl moiety of the Nod factors.

\section{Sequence analysis of the nolL gene.}

We sequenced $2 \mathrm{~kb}$ of the Bam HI band 81 (GenBank accession number AF047684) from the pSym CE3. Computer analysis of this sequence revealed an open reading frame of $1,176 \mathrm{bp}$, coding for a polypeptide of 392 aa. A BLAST search (Altschul
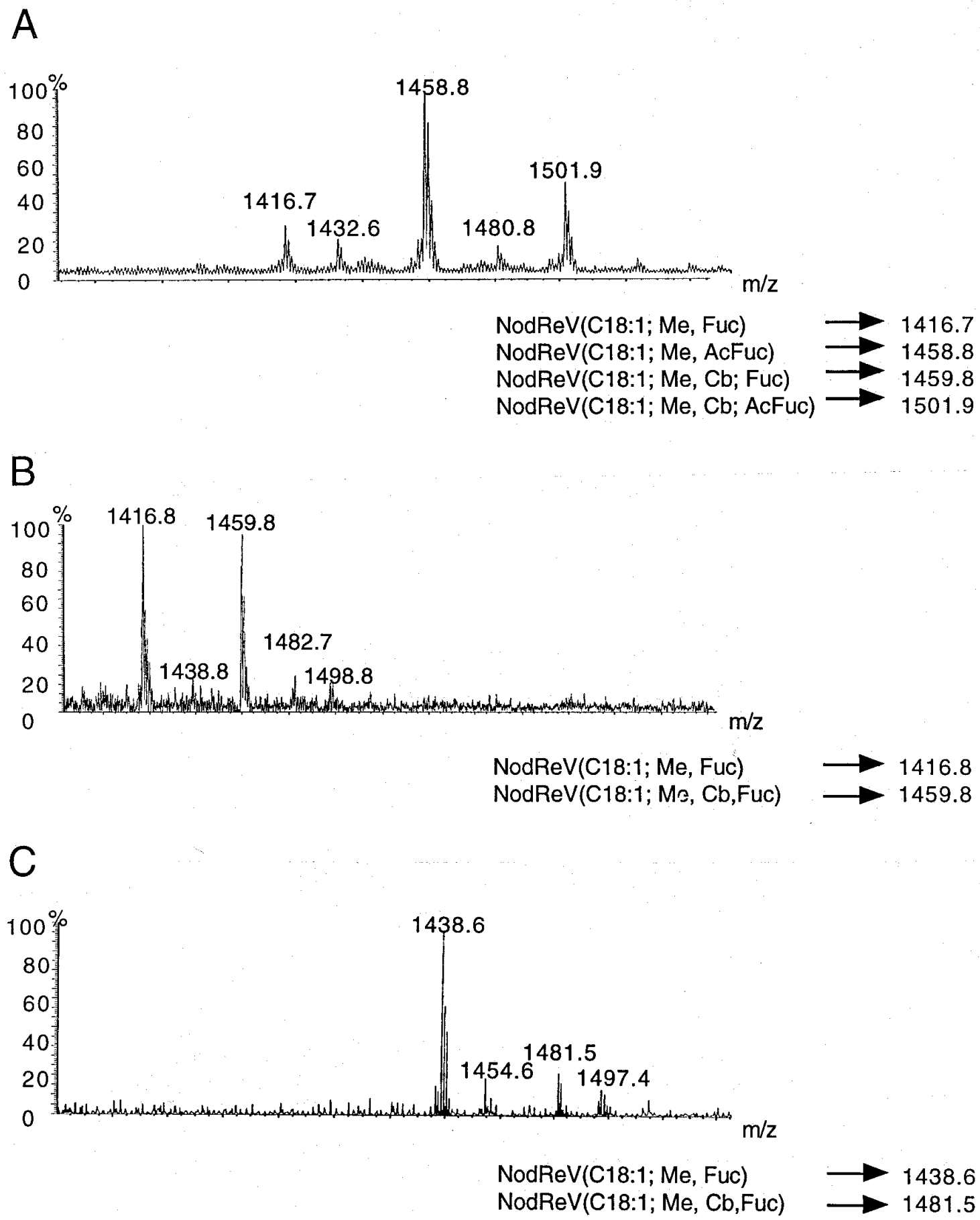

Fig. 3. Liquid secondary ion mass spectrometry (LSIMS) analysis and chemical structure of the main compounds produced, upon genistein induction, by strains (A) CE3, (B) CFNX250 (both in an acidified matrix), and (C) CFNX289 (after addition of sodium iodide). Minor peaks are described in text. 
et al. 1990, 1997) showed that the nolL gene of $R$. etli has a high similarity with the nolL genes from Rhizobium loti (Scott et al. 1996) and Rhizobium sp. strain NGR234 (Freiberg et al. 1997). Both species also carry acetyl-fucose substituents on their Nod factors. At the protein level, the predicted NolL protein from $R$. etli is $48.7 \%$ identical and $76.3 \%$ similar to its counterpart in $R$. loti, and $48 \%$ identical and $74.2 \%$ similar to its homolog in Rhizobium sp. strain NGR234. Weaker similarities were also observed with two acetyl-transferases: the Oac (also called GumF; accession numbers X78451 and U22511), and the GumG (accession number U22511) proteins from Xanthomonas campestris, and with a hypothetical protein from $\mathrm{Ba}$ cillus subtilis (accession number Z99111).

We also used the Position-Specific Iterated-BLAST (PSIBLAST) program, which constructs a position-specific scorematrix based on original alignments generated by BLAST; this matrix is then used for new searches, and is more sensitive to detect weak relationships that are often of great biological relevance (Altschul et al. 1997). Our results show that the NolL protein has also significant sequence similarities (along the whole protein) with several acetyl- and acyltransferases of the family of IMTs (Slauch et al. 1996). Among these are the Oac protein from Shigella phage SF6, the Lag1 protein from Legionella pneumophila, the NodX protein from $R$. leguminosarum bv. viciae, the Mpt protein of Streptomyces thermotolerans, the MdmB protein from S. mycarofaciens, and some hypothetical proteins from Caenorhabditis elegans. Some similarity is also seen with the ExoH protein from $R h i$ zobium meliloti (a succinyl-transferase) and with several other transmembranal proteins with a variety of functions.

An alignment between the NolL proteins and some proteins of the family of IMTs shows that they all share the first one of the two regions of homology previously detected among the members of the family; this region is the only one that was reported as conserved in the GumF protein (Slauch et al. 1996; Fig. 4). These structural similarities establish that the NolL proteins are members of the family of IMTs.

\section{The NolL protein may be transmembranal.}

An interesting feature of the NolL protein from $R$. etli is that it has nine potential transmembranal $\alpha$-helices (predicted by the TMpred program, among others; Hofmann and Stoffel
1993; Fig. 5). It lacks an apparent leader peptide, thus it would be located in the inner membrane of the cell (as predicted by the PSORT program; Nakai and Kanehisa 1991). These characteristics are shared by the NolL proteins from both $R$. loti and Rhizobium sp. strain NGR234 (data not shown), thus confirming that NolL should be included within the proteins of the family of IMTs.

The high hydrophobicity of the NolL proteins and their putative transmembranal location have led to speculations that the NolL protein might be a transporter; thus, they were annotated initially as possible transport proteins (accession number 2498660 for $R$. loti, accession number 2498661 for Rhizobium sp. strain NGR234). To rule out this possibility, we extracted the nodulation factors accumulated inside the cell and visualized them on TLC plates (Fig. 2B). Results show that the nodulation factors synthesized and accumulated inside the cell (Fig. 2B) are the same kind of Nod factors that are secreted from the cell (Fig. 2B). These data demonstrate that mutant strains are not synthesizing acetylated compounds.

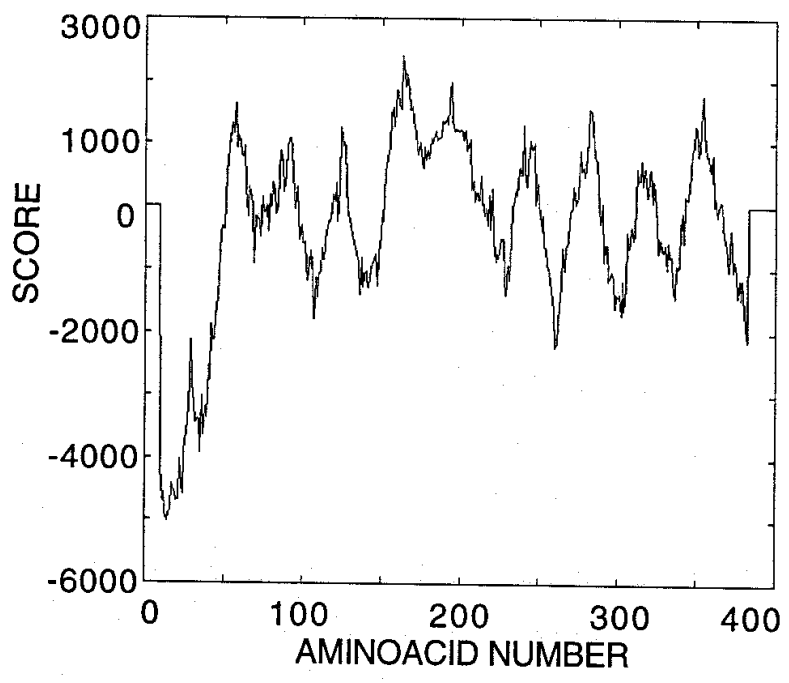

Fig. 5. Hydropathy profile of the predicted NolL protein from Rhizobium etli CE3 (according to the TMpred program; prediction was done with a window of 21 to 33 amino acids per helix).

\begin{tabular}{|c|c|c|c|}
\hline ExoZ & IGAAGVDVFFVISGFIMW & $\ldots \ldots \ldots \ldots$ VISDRRSVTPVE & FIADRARRIVPVY \\
\hline OafA & GGFIGVDVFFVISGFLMT & GIVLERVDHKGVLD . . . . . . . & FYIARFLRIVPAL \\
\hline NodX & FSAPGVAIFFLISGFLVT & $\ldots \ldots \ldots$ DSYIRSSSAAS & FFVKRSLRIFPAL \\
\hline Oac.SF6 & AGGIAVIIFFSISGYLIS & $\ldots \ldots \ldots \ldots \ldots \ldots$ KSAIRSDSFID & FMAKRARRIFPAL \\
\hline Lag1 & FQSLAVNAFFWLSGFLIT & ..... YHCITKKPY . . . TFAE & YMIDRFCRIYVIY \\
\hline NolL-NGR & IYMFHMPLFMAISGYLAS & ........GTILRTSFCR & AVGDRAVQLLIPM \\
\hline NolL-loti & IYMFHMPLFMAISGYLSS & $\ldots \ldots \ldots \ldots \ldots$. . . . . . . . & GVGERAMQLLLPM \\
\hline NolL-etli & IYMFHMPLFMAISGYLSR & . . SGLLGKSFRQ & AIGDRALQLLVPT \\
\hline GumF & AYSFHVPLFFLVSGWLAA & . . . . GYASRTTSLL & QTITKQARGLLLP \\
\hline GumG & AYSFHVPLFFVLSGWVGE & ...... RFGRRAFGR & KTVGKLARTLLIP \\
\hline $\begin{array}{l}\text { Consensus } \\
\text { Cons.FIMT }\end{array}$ & $\begin{array}{l}\text {-YMFHVPLFF-ISG-L-- } \\
\text { ngflgVdiFFVISGfLma }\end{array}$ & 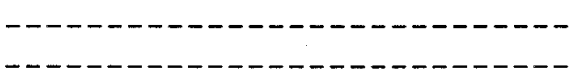 & $\begin{array}{l}\text { F-GDRALRILP-- } \\
\text { Fy-rRE-RIYPI- }\end{array}$ \\
\hline
\end{tabular}

Fig. 4. Consensus sequences between some members of the family of integral membrane trans-acylases (FIMT) and the NolL proteins. Alignment was done with the PILEUP program and subsequent manual adjustment. Consensus both for the alignment and for the first conserved motif previously defined for the FIMT (Slauch et al. 1996) are shown (capital letters represent those amino acids conserved in both consensus sequences). 
Our data show that the NolL protein does not determine a differential secretion from inside the cell, thus ruling out a possible role as a discriminating transporter between acetylated and nonacetylated molecules.

\section{The nolL gene is not induced by genistein.}

The nolL gene is transcribed clockwise with respect to the reported physical map of the pSym CE3 (Girard et al. 1991; and data not shown). We found a potential nod-box 489 bp upstream of the initial predicted methionine (not shown). The identified nod-box sequence presents the 3-bp inverted repeats that are part of the T- $\mathrm{N}_{11}-\mathrm{A}$ LysR type motif, which occurs twice in the sequence. These two motifs represent those sites where the NodD dimer may bind. The nod-box shows 10 mismatches when compared with the consensus sequence reported by Van Rhijn and Vanderleyden (1995). Sequence conservation suggests that the gene may be regulated by the NodD-flavonoid regulatory circuit. This observation could be in accordance with a previous report of strong transcriptional activity detected on band 81 upon induction with genistein (Girard et al. 1996). To test if nolL is responsive to genistein induction, we made a transcriptional fusion with the promoter region of the nolL gene and a promoterless gusA gene. The resulting plasmid (pACP6) was introduced in wild-type CE3. Gus expression assays were performed, as described in Materials and Methods, on strains grown in minimal medium in the presence and in the absence of genistein. We found that expression of the gusA gene is the same in both induced and uninduced cultures (data not shown). Thus, the expression of the nolL gene is independent of genistein induction.

\section{Acetylation on the fucose is a determinant for an efficient nodulation.}

Nodulation kinetics assays were performed on plants of common bean (Phaseolus vulgaris) cvs. Negro Jamapa, Canario 101, and L3-111-CM and on two alternative hosts for $R$. etli (Hernández-Lucas et al. 1995): rice bean (Vigna umbellata) and cowpea (Vigna unguiculata). A Student's $t$ test statistical analysis $(P=0.01$; data not shown) shows that the mutant strain, CFNX289, forms a significantly lower number of nodules on $P$. vulgaris cv. L3-111-CM and on V. umbellata plants than the wild-type strain (Fig. 6B and C). In contrast, total nodule formation was unaltered on plants of $P$. vulgaris cvs. Negro Jamapa (Fig. 6A) or Canario 101, or on plants of $V$. unguiculata (data not shown).

Our data indicate that acetylation of the fucosyl residue is important for an efficient nodulation of some plant cultivars and of some species.

The nolL gene is also conserved in other strains of $R$. etli.

The nolL gene of $R$. etli CE3 may be widely distributed among the nodulating strains of the species. High-stringency hybridization analysis showed that it is present in the nine strains tested: CFN-1, NITRAGIN-8251, BRA-5, KIM 5, TAL-182, CIAT-894, CIAT-895, 127K81-3, and VIKING-1 (data not shown).

\section{DISCUSSION}

We show here that the nolL gene from $R$. etli is clearly involved in the 4-O-acetylation step of the fucosyl residue of the
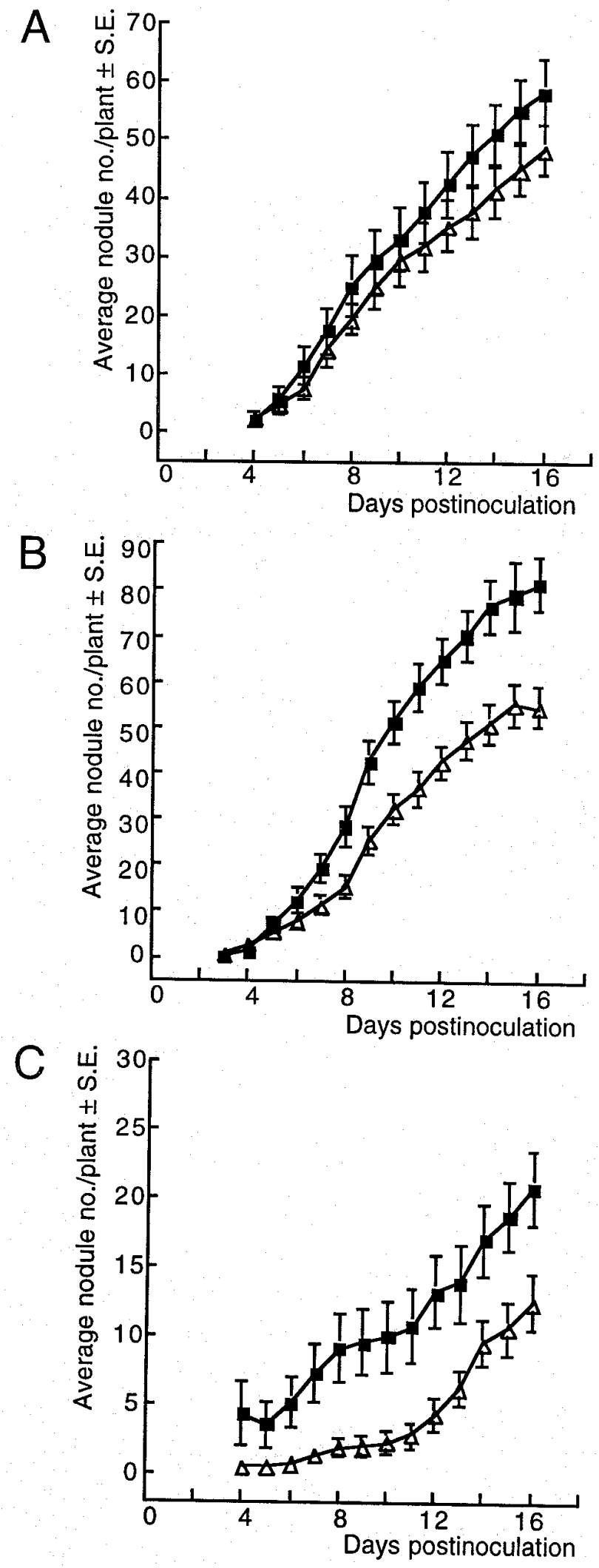

Fig. 6. Nodulation kinetics of strains CE3 (filled squares) and CFNX289 (empty triangles), on plants of (A) Phaseolus vulgaris cv. Negro Jamapa, (B) Phaseolus vulgaris cv. L3-111-CM, and (C) Vigna umbellata. 
nodulation factors in $R$. etli CE3. This conclusion is based on TLC analysis of the Nod factors produced by different strains, as well as by direct structural determination by mass spectrometry. To analyze these results, it should be kept in mind that TLC plate assay results were only evaluated qualitatively and not quantitatively. Occasional quantitative differences that can be seen on TLC plates among the compounds produced by the whole set of strains may be due to the fact that they have different plasmid copy numbers (i.e., pSym CE3 has a different copy number than pGM1, and they both have different copy numbers than pRK7813; data not shown), thus having different nod and nol gene copy numbers. Also, the concentration of Nod factors may vary between the strains depending on the bacterial capacity of synthesizing or not the whole set of Nod factors, in comparison to the wild-type strain. Some precursors may accumulate in those strains that are not able to produce the whole Nod factor mixture. Thus, when talking about phenotypes on TLC plates and/or Nod factor production, we refer to equal number of bands in TLC profiles, and not to equal concentration of the compounds produced. Despite these variations, the chemical composition of the Nod factors produced by the mutant strain, which lack the acetylsubstituent on the fucose, strongly suggests that NolL may be an acetyl-transferase, as has been proposed for the NolL protein of $R$. loti (Scott et al. 1996). This hypothesis is reinforced by the similarity between the three different NolL proteins reported and the members of the family of IMTs (Slauch et al. 1996).

As new members of the family of IMTs, the NolL proteins from $R$. etli, R. loti, and Rhizobium sp. strain NGR234 have a hydrophobic nature that makes them perfect candidates for being transmembranal.

A common misconception is that integral membrane proteins usually lack enzymatic activity; most of them are thought to be structural proteins or transporters. However, our data show that the NolL protein is not a differential transporter of nodulation factors, but that it is playing an important role in acetylation. Besides the examples of acetyl- or acyltransferases that belong to the same family as NolL, further examples exist of synthases and synthetases, such as CDPdiglyceride synthases (see for example Shen et al. 1996), that are in the cytoplasmic membrane and catalyze the synthesis of some compounds, and of a eukaryotic transmembranal acetyltransferase in the lysosomes of human cells (Meikle et al. 1995).

The presence of a putative nod-box upstream of the nolL gene from $R$. etli suggested that the gene might be regulated by the NodD protein. The nolL gene from Rhizobium sp. strain NGR234 also has a putative nod-box associated with it (277 bp upstream of the predicted open reading frame; Freiberg et al. 1997), while this is not the case for the gene of $R$. loti (Scott et al. 1996). GusA fusion assays demonstrated that the expression of the nolL gene of R. etli CE3 is independent of the induction by genistein.

The phenotypical characteristics of the nolL strain demonstrate that the acetylation on the fucose is a determinant for an efficient nodulation of $P$. vulgaris cv. L3-111-CM and of $V$. umbellata. Our data are in agreement with previous results obtained with nolL strains from $R$. loti, in which the nodulation of Lotus pedunculatus plants was delayed and nodulation of Leucaena leucocephala was abolished (Scott et al. 1996), demonstrating that acetylation of the fucosyl residue is an important determinant for nodulation efficiency and host range. These data indicate that a nodulation gene may act in different ways, with quantitative effects on nodulation or modulating host range, under Pueppke's (1996) classification of nodulation genes, perhaps in response to unknown stimuli.

Quinto and collaborators (1997) showed, based on in vitro experiments, that NodZ is able to transfer a fucosyl residue (that is not acetylated) to the core oligosaccharide of the nodulation factor. Our in vivo data confirm that acetylation is not necessary for the addition of the fucose to the reducing glucosamine. The precise mechanism of Nod factor synthesis and its cellular localization is still unknown. It has been proposed that an anchor molecule, probably undecaprenol pyrophosphate, may be functioning during the biosynthesis of nodulation factors (Carlson et al. 1994). This carrier molecule would keep the growing molecule near the site where NodC is attached to the inner membrane, where a sequential addition of sugars would take place. Cytoplasmic proteins such as NodAB could easily access the nonreducing end of the Nod factor to act on it. This would not be so easy in the case of those cytoplasmic proteins such as NodZ, which act on the reducing end of the molecule. Nevertheless, growth of a polysaccharide can occur at the reducing terminus by joining two undecaprenol-linked molecules (reviewed in Whitfield and Valvano 1993). Examples of acetylation as a postpolymerization modification have also been described during the synthesis of $O$-polysaccharides of Salmonella enterica, Xanthomonas campestris (reviewed in Whitfield and Valvano 1993), and Neisseria meningitidis (Vann et al. 1978), among others.

In conclusion, our data clearly show that NolL is involved in acetylation of the nodulation factor, and that it is functioning most probably as an acetyl-transferase. Further support for this proposal will be obtained through the purification and biochemical characterization of the NolL protein.

\section{MATERIALS AND METHODS}

\section{Bacterial strains and growth conditions.}

Bacterial strains and plasmids used in this study are listed in Table 1. Rhizobium strains were grown in PY rich medium (Noel et al. 1984) at $30^{\circ} \mathrm{C}$. Escherichia coli strains were grown at $37^{\circ} \mathrm{C}$ in LB medium (Sambrook et al. 1989). When required, antibiotics were added to the medium at the following concentrations: nalidixic acid (Nal): $20 \mu \mathrm{g} \mathrm{m}{ }^{-1}$, for both Rhizobium strains and E. coli; tetracycline (Tc): $10 \mu \mathrm{g} \mathrm{ml}^{-1}$ for E. coli and 2 to $5 \mu \mathrm{g} \mathrm{m} \mathrm{m}^{-1}$ for Rhizobium strains; kanamycin (Km): 15 to $30 \mu \mathrm{g} \mathrm{ml}^{-1}$ for both Rhizobium and E. coli; gentamycin $(\mathrm{Gm}): 15 \mu \mathrm{g} \mathrm{ml}^{-1}$. For homogenotization experiments, sucrose was employed at a concentration of $12.5 \%$ (Gay et al. 1985).

\section{Complementation assays.}

All genetic manipulations were carried out by standard procedures. $R$. etli CFNX250 was complemented (for wild-type production of nodulation factors) with several fragments from the symbiotic plasmid from wild-type strain CE3. Sequential complementation assays were performed by introducing smaller fragments each time. DNA fragments were introduced by standard conjugation techniques, with plasmid pRK2073 as a helper plasmid, when needed. Complementation for wild- 
type production of nodulation factors was detected by TLC analysis (see below).

Extraction of nodulation factors for TLC and MS analysis.

Cultures grown for $24 \mathrm{~h}$ on PY plates were used to inoculate minimal medium (Girard et al. 1996). Cultures were inoculated at an initial $\mathrm{OD}_{600}$ of 0.1 and grown with shaking (200 rpm; Incubator Shaker G26, New Brunswick Scientific, Edison, NJ) for $15 \mathrm{~h}$ at $30^{\circ} \mathrm{C}$ in the presence of $1.2 \mu \mathrm{M}$ genistein.

Cultures $(1 \mathrm{ml})$ with $0.2 \mu \mathrm{Ci}$ of $\mathrm{D}-\left[1-{ }^{14} \mathrm{C}\right]$ glucosamine hydrochloride (added to the culture $3 \mathrm{~h}$ after genistein induction) were used for TLC analysis. Secreted nodulation factors were extracted from the supernatants as described previously (Mendoza et al. 1995). Nodulation factors accumulated in membranes were also extracted from culture pellets (modified from Orgambide et al. 1995), after washing with $50 \mu \mathrm{l}$ of sterile water, with a mixture of chloroform/1-propanol/methanol/ water $(1: 2: 2: 3$, vol/vol). Extraction matrix-culture pellet mixtures were kept in agitation (100 rpm; Environ-shaker 3597, Lab-Line Instruments, Melrose Park, IL) for $6 \mathrm{~h}$ at $37^{\circ} \mathrm{C}$; cultures were then centrifuged, and the supernatants were collected and vacuum dried (at a high drying rate in a SpeedVac SVC100; Savant, Farmingdale, NY) for $50 \mathrm{~min}$. Extracted material was taken up in $40 \mu \mathrm{l}$ of methanol and analyzed by TLC. Control cultures were treated similarly but without genistein induction.

Cultures (1 liter) were centrifuged and the supernatant was extracted with $900 \mathrm{ml}$ of butanol. The butanol extract was vacuum evaporated to dryness at a temperature of 60 to $70^{\circ} \mathrm{C}$ The residue was dissolved in $20 \mathrm{ml}$ of water, and vacuum dried once again (at a high drying rate in a SpeedVac SVC100; Savant). MS analysis was used to determine chemical composition of samples.

\section{Structural analysis of the nodulation factors.}

Extracts from strains CE3 and CFNX250 were solubilized in water and injected on a C-18 reversed phase HPLC column (Spherisorb, ODS1, $5 \mu \mathrm{m}, 250 \times 4.6 \mathrm{~mm}$ ) with the $\mathrm{H}_{2} \mathrm{O}$ :acetonitrile gradient already described (Poupot et al, 1995). The HPLC trace was visualized by UV absorption at $206 \mathrm{~nm}$. A wide fraction eluting after the genistein peak was collected, evaporated, and analyzed by LSIMS. For strain CFNX289, the HPLC step was omitted and the crude butanol extract was analyzed by MS directly.

Mass spectra were recorded on an AutoSpec instrument (Micromass, Manchester, UK) fitted with a cesium gun. The matrix was a mixture of metanitrobenzyl alcohol/glycerol (1:1, vol/vol) spiked either with trichloroacetic acid (for CE3 and CFNX250 samples) or with sodium iodide (CFNX289 sample).

\section{Genetic manipulations.}

The pACP1 plasmid is a derivative of plasmid pRK7813 (Jones and Gutterson 1987) carrying the 3.8-kb BamHI band 81 from the pSym CE3 (Girard et al. 1991), containing the nolL gene. The nolL gene was mutagenized by introducing a 1,454-bp NheI fragment from the $\Omega-\mathrm{Km}$ element from pBSL128 (Alexeyev et al. 1995) in the unique NheI site within the nolL gene in pACP1, generating pACP3. Plasmid pACP3 was digested with $B a m \mathrm{HI}$ restriction enzyme and the
nolL::Km fragment was subcloned in plasmid pWM91 (Metcalf et al. 1996) to construct plasmid pACP4. Since this plasmid requires the Pir protein for replication, pACP4 was maintained in strain BW21038.

Conjugative transfer of pACP4 to strain CE3 and selection for sucrose and Km-resistant derivatives resulted in double recombination of the nolL gene and the $\mathrm{Km}$ cassette, thus generating strain CFNX289. Southern blot hybridization analysis, with both band 81 and pWM91 as probes, confirmed the presence of the Km cassette.

A 1,911-bp product of a polymerase chain reaction over pACP1, with universal primer reverse and a specific primer called BOX1 (5'-GCGGCCAAAGCTTCGTGTATC-3'), was cloned in plasmid pMOS with the pMOSBlueT kit (Amersham, Buckinghamshire, U.K.); the 1,872-bp BamHI fragment containing the nolL gene was then subcloned in pRK7813 (Jones and Gutterson 1987), giving rise to plasmid pACP5.

Plasmid pACP6 is a derivative of the promoter-probe plasmid pBBMCS53 (L. Girard, unpublished), carrying a 2.8-kb EcoRI fragment from band 81 from the pSym CE3.

\section{Hybridization assays.}

Total DNA was extracted from different strains of $R$. etli with a DNA/RNA extraction kit (Amersham), following the manufacturer's instructions. Total DNA was digested with the restriction enzyme BamHI, electrophoresed in $1 \%$ (wt/vol) agarose gels, and transferred to nylon membranes (Hybond $\mathrm{N}^{+}$; Amersham) by the standard Southern blot method (Ausubel et al, 1989). Hybridization was performed under high stringency conditions with rapid-hybridization buffer (Amersham) and Redi-prime (random primer labeling; Amersham).

\section{Sequencing analysis.}

Sequencing analysis was done with DNA from plasmid pACP1. Universal primers (reverse: 5'-GGAAACAGCTATG ACCATGATTACGCC-3' and -21: 5'-TGTAAAACGACG GCCAGT-3') were used for initial sequencing stages. Whole sequence from the nolL gene was achieved by primer walking, with custom-made oligonucleotides (Biosynthesis, Lewisville, TX, and Laboratorio de Síntesis de Macromoléculas, Instituto de Biotecnología, UNAM). Sequencing was done on both coding and noncoding strands with a thermo sequenase cycle sequencing kit (Amersham). Oligonucleotides were labeled by kinasing with $\left[\gamma^{33} \mathrm{P}\right] \mathrm{ATP}$, following the manufacturer's instructions.

\section{GUS fusion assays.}

Strains carrying either pBBMCS53 or pACP6 were cultured under the same conditions as those used for extraction of nodulation factors. Parallel cultures were grown in the presence and absence of genistein, one sample tube for each one of the conditions and times tested. After 1, 4, 8, 15, and $24 \mathrm{~h}$ of incubation, $1.5 \mathrm{ml}$ of culture was centrifuged and resuspended in a salts wash solution $\left(\mathrm{MgSO}_{4} 0.01 \%, \mathrm{~K}_{2} \mathrm{HPO}_{4}\right.$ $0.022 \%)$ supplemented with chloramphenicol (100 $\mu \mathrm{g} / \mathrm{ml})$. Resuspended cultures were kept at $-70^{\circ} \mathrm{C}$. Quantitative GUS ( $\beta$-glucuronidase) assays were performed with $p$-nitrophenyl glucuronide as substrate as previously described (Wilson et al. 1992), but GUS assay buffer was prepared with $50 \mathrm{mM} \mathrm{KPO}_{4}$, $\mathrm{pH} 7.0$ buffer instead of $50 \mathrm{mM} \mathrm{NaPO}_{4}, \mathrm{pH} 7.0$ buffer. 
Data were normalized to total cell protein concentration by the Lowry method (Ausubel et al. 1996) over a second set of 1.5-ml samples.

\section{Plant assays.}

Surface-sterilized seeds from $P$. vulgaris (common bean) cvs. Negro Jamapa, L3-111-CM, and Canario 101, and from $V$. umbellata (rice bean) and $V$. unguiculata (cowpea) were germinated on $\mathrm{H}_{2} \mathrm{O}-0.8 \%$ agar plates for 2 to 3 days. Seedlings were then transplanted to 250 -ml Erlenmeyer flasks containing $\mathrm{N}$-free Fahraeus (1957) solution-0.8\% agar, and inoculated with $1 \times 10^{7}$ cells $\mathrm{ml}^{-1}$ of the corresponding strain. Plants were kept in a culture chamber, under a 12-h light/dark period. Roots were covered with black plastic pouches to protect them from light. Nodulation kinetics were recorded as the accumulated number of nodules formed through time. Control plants were inoculated with sterile water.

\section{ACKNOWLEDGMENTS}

We are indebted to Susana Brom for critical reviewing of the manuscript; to Patricia Bustos and Guillermo Dávila for helping with initial stages of sequencing and providing unpublished sequence data; to Marco A. Rogel and Paul Gaytán, for their help in extraction of nodulation factors; to Lourdes Girard for giving us plasmid pBBMCS53; and to Javier Rivera for helping with some of the plant assays. We acknowledge J. J. Peña-Cabriales, S. Pueppke, and PRONASE (México) for providing seeds. Partial financial support for this research was provided by PAPIIT-UNAM (grant IN201595) and PADEP-UNAM (grants 030389 and 030329). A. C. was a recipient of scholarships from the Consejo Nacional de Ciencia y Tecnología and DGAPA-UNAM (México).

\section{LITERATURE CITED}

Alexeyev, M. F., Shokolenko, I. N., and Croughan, T. P. 1995. Improved antibiotic-resistance cassettes and omega elements for Escherichia coli vector construction and in vitro deletion/insertion mutagenesis. Gene 160:63-67.

Altschul, S. F., Gish, W., Miller, W., Myers, E. W., and Lipman, D. J. 1990. Basic local alignment search tool. J. Mol. Biol. 215:403-410.

Altschul, S. F., Madden, T. L., Schäffer, A. A., Zhang, J., Zhang, Z., Miller, W., and Lipman, D. L. 1997. Gapped BLAST and PSIBLAST: A new generation of protein database search programs. Nucleic Acids Res. 25:3389-3402.

Ausubel, F. M., Brent, R., Kingston, R. E., Moore, D. D., Seidman, J. G., Smith, J. A., and Struhl, K., eds. 1989. Short Protocols in Molecular Biology. John Wiley \& Sons, New York.

Ausubel, F. M., Brent, R., Kingston, R. E., Moore, D. D., Seidman, J. G., Smith, J. A., and Struhl, K., eds. 1996. Current Protocols in Molecular Biology. John Wiley \& Sons, New York.

Better, M., and Helinski, D. P. 1983. Isolation and characterization of a recA gene of Rhizobium meliloti. J. Bacteriol. 115:311-316.

Bladergroen, M. R., and Spaink, H. P. 1998. Genes and signal molecules involved in the rhizobia-Leguminoseae symbiosis. Curr. Opin. Plant Biol. 1:353-359.

Brom, S., García de los Santos, A., Stepkowsky, T., Flores, M., Dávila, G., Romero, D., and Palacios, R. 1992. Different plasmids of Rhizobium leguminosarum bv. phaseoli are required for optimal symbiotic performance. J. Bacteriol. 174:5183-5189.

Cárdenas, L., Domínguez, J., Quinto, C., López-Lara, I. M., Lugtenberg, B. J. J., Spaink, H. P., Rademaker, G. J., Haverkamp, J., and ThomasOates, J. E. 1995. Isolation, chemical structures and biological activity of the lipo-chitin oligosaccharide nodulation signals from Rhizobium etli. Plant Mol. Biol. 29:453-464.

Carlson, R. W., Price, N. P. J., and Stacey, G. 1994. The biosynthesis of rhizobial lipo-oligosaccharide nodulation signal molecules. Mol. Plant-Microbe Interact. 7:684-695.

Dénarié, J., Debellé, F., and Promé, J.-C. 1996. Rhizobium lipochitooligosaccharide nodulation factors: Signaling molecules medi- ating recognition and morphogenesis. Annu. Rev. Biochem. 65:503535.

Dénarié, J., Truchet, G., and Promé, J.-C. 1994. Rhizobium nodulation factors: Synthesis and induction of plant responses. Pages 81-90 in: Advances in Molecular Genetics of Plant-Microbe Interactions. Vol. 3. M. J. Daniels, J. A. Downie, and A. E. Osbourn, eds. Kluwer Academic Pub., Dordrecht, The Netherlands.

Fahraeus, G. 1957. The infection of clover root hairs by nodule bacteria studied by a simple glass slide technique. J. Gen. Microbiol. 16:374381.

Fisher, R. F., and Long, S. R. 1992. Rhizobium-plant signal exchange. Nature 357:655-659.

Freiberg, C., Fellay, R., Bairoch, A., Broughton, W. J., Rosenthal, A., and Perret, X. 1997. Molecular basis of symbiosis between Rhizobium and legumes. Nature 387:394-401.

Gay, P., Le Coq, D., Steinmetz, M., Berkelman, T., and Kado, C. I. 1985. Positive selection procedure for entrapment of insertion sequence elements in gram-negative bacteria. J. Bacteriol. 164:918-921.

Girard, M. L., Flores, M., Brom, S., Romero, D., Palacios, R., and Dávila, G. 1991. Structural complexity of the symbiotic plasmid of Rhizobium leguminosarum bv. phaseoli. J. Bacteriol. 173:2411-2419.

Girard, L., Valderrama, B., Palacios, R., Romero, D., and Dávila, G. 1996. Transcriptional activity of the symbiotic plasmid of Rhizobium etli is affected by different environmental conditions. Microbiology 142:2847-2856.

Hernández-Lucas, I., Segovia, L., Martínez-Romero, E., and Pueppke, S. 1995. Phylogenetic relationships and host range of Rhizobium spp. that nodulate Phaseolus vulgaris L. Appl. Environ. Microbiol. 61: 2775-2779.

Hofmann, K., and Stoffel, W. 1993. TMbase-A database of membrane spanning protein segments. Biol. Chem. Hoppe-Seyler 347:166.

Jones, J. D. G., and Gutterson, N. 1987. An efficient mobilizable cosmid vector, pRK7813, and its use in a rapid method for marker exchange in Pseudomonas fluorescens strain HV37a. Gene 61:299-306.

Josephson, K. L., and Pepper, I. L. 1984. Competitiveness and effectiveness of strains of Rhizobium phaseoli isolated from the Sonoran desert. Soil Biol Biochem. 16:651-655.

Kovach, M. E., Elzer, P. H., Hill, D. S., Robertson, G. T., Farris, M. A., Roop, R. M., II, and Peterson, K. M. 1995. Four new derivatives of the broad-host-range cloning vector pBBR1MCS, carrying different antibiotic-resistance cassettes. Gene 166:175-176.

Meikle, P. J., Whittle, A. M., and Hopwood, J. J. 1995. Human acetylcoenzyme A: $\alpha$-Glucosaminide $N$-acetyltransferase. Kinetic characterization and mechanistic interpretation. Biochem. J. 308: 327-333.

Mendoza, A., Leija, A., Martínez-Romero, E., Hernández, G., and Mora, J. 1995. The enhancement of ammonium assimilation in Rhizobium etli prevents nodulation of Phaseolus vulgaris. Mol. Plant-Microbe Interact. 8:584-592.

Metcalf, W. W., Jiang, W., Daniels, L. L., Kim, S.-K., Haldimann, A., and Wanner, B. L. 1996. Conditionally replicative and conjugative plasmids carrying lacZ $\alpha$ for cloning, mutagenesis, and allele replacement in bacteria. Plasmid 35:1-13.

Metcalf, W. W., and Wanner, B. L. 1993. Construction of new Bglucuronidase cassettes for making transcriptional fusions and their use with new methods for allele replacement. Gene 129:17-25.

Mylona, P., Pawlowski, K., and Bisseling, T. 1995. Symbiotic nitrogen fixation. Plant Cell 7:869-885.

Nakai, K., and Kanehisa, M. 1991. Expert system for predicting protein localization sites in gram-negative bacteria. Proteins 11:95-110.

Noel, K. D., Sánchez, A., Fernández, L., Leemans, J., and Cevallos, M. A. 1984. Rhizobium phaseoli symbiotic mutants with transposon Tn5 insertions. J. Bacteriol. 158:148-155.

Orgambide, G. G., Lee, J., Hollingsworth, R. I., and Dazzo, F. B. 1995. Structurally diverse chitolipooligosaccharide Nod factors accumulate primarily in membranes of wild-type Rhizobium leguminosarum biovar trifolii. Biochemistry 34:3832-3840.

Piñero, D., Martínez, E., and Selander, R. K. 1988. Genetic diversity and relationships among isolates of Rhizobium leguminosarum biovar phaseoli. Appl. Environ. Microbiol. 54:2825-2832.

Poupot, R., Martínez-Romero, E., Gautier, N., and Promé, J.-C. 1995. Wild type Rhizobium etli, a bean symbiont, produces acetylfucosylated, $N$-methylated, and carbamoylated nodulation factors. J. Biol. Chem. 270:6050-6055.

Pueppke, S. G. 1996. The genetic and biochemical basis of nodulation 
of legumes by Rhizobia. Crit. Rev. Biotechnol. 16:1-51.

Quinto, C., de la Vega, H., Flores, M., Fernández, L., Ballado, T., Soberón, G., and Palacios, R. 1982. Reiteration of nitrogen fixation gene sequences in Rhizobium phaseoli. Nature 299:724-726.

Quinto, C., Wijfjes, A. H. M., Bloemberg, G. V., Blok-Tip, L., LópezLara, I. M., Lugtenberg, B. J. J., Thomas-Oates, J. E., and Spaink, H. P. 1997. Bacterial nodulation protein NodZ is a chitin oligosaccharide fucosyltransferase which can also recognize related substrates of animal origin. Proc. Natl. Acad. Sci. USA 94:4336-4341.

Relić, B., Perret, X., Estrada-García, M. T., Kopcinska, J., Golinowski, W., Krishnan, H. B., Pueppke, S. G., and Broughton, W. J. 1994. Nod factors of Rhizobium are a key to the legume door. Mol. Microbiol. 13:171-178.

Relić, B., Talmont, F., Kopcinska, J., Golinowski, W., Promé, J.-C., and Broughton, W. J. 1993. Biological activity of Rhizobium sp. NGR234 Nod-factors on Macroptilium atropurpureum. Mol. Plant-Microbe Interact. 6:764-774.

Romero, D., Martínez-Salazar, J., Girard, L., Brom, S., Dávila, G., Palacios, R., Flores, M., and Rodríguez, C. 1995. Discrete amplifiable regions (Amplicons) in the symbiotic plasmid of Rhizobium etli CFN42. J. Bacteriol. 177:973-980.

Sambrook, J., Fritsch, E. F., and Maniatis T. A. 1989. Molecular Cloning: A Laboratory Manual. 2nd ed. Cold Spring Harbor Laboratory, Cold Spring Harbor, NY.

Schultze, M., Kondorosi, É., Ratet, P., Buiré, M., and Kondorosi, A. 1994. Cell and molecular biology of Rhizobium-plant interactions. Int. Rev. Cytol. 156:1-75.

Scott, D. B., Young, C. A., Collins-Emerson, J. M., Terzaghi, E. A., Rockman, E. S., Lewis, P. E., and Pankhurst, C. E. 1996. Novel and complex chromosomal arrangement of Rhizobium loti nodulation genes. Mol. Plant-Microbe Interact. 9:187-197.

Segovia, L., Young, J. P. W., and Martínez-Romero, E. 1993. Reclassification of American Rhizobium leguminosarum biovar phaseoli type I strains as Rhizobium etli sp. nov. Int. J. Syst. Bacteriol. 43:374-377.

Shen, H., Heacock, P. N., Clancey, C. J., and Dowhan, W. 1996. The
CDS1 gene encoding CDP-diacylglycerol synthase in Saccharomyces cerevisiae is essential for cell growth. J. Biol. Chem. 271:789-795.

Slauch, J. M., Lee, A. A., Mahan, M. J., and Mekalanos, J. J. 1996. Molecular characterization of the oafA locus responsible for acetylation of Salmonella typhimurium O-antigen: OafA is a member of a family of integral membrane trans-acylases. J. Bacteriol. 178:59045909.

Spaink, H. P. 1995. The molecular basis of infection and nodulation by Rhizobia: The ins and outs of sympathogenesis. Annu. Rev. Phytopathol. 33:345-368.

Sprent, J., and Sprent, P. 1990. Nitrogen Fixing Organisms. Pure and Applied Aspects. Chapman and Hall, Cambridge.

Staehelin, C., Granado, J., Müller, J., Wiemken, A., Mellor, R. B., Felix, G., Regenass, M., Broughton, W. J., and Boller, T. 1994. Perception of Rhizobium nodulation factors by tomato cells and inactivation by root chitinases. Proc. Natl. Acad. Sci. USA 91:2196-2200.

Van Rhijn, P., and Vanderleyden, J. 1995. The Rhizobium-plant symbiosis. Microbiol. Rev. 59:124-142.

Vann, W. F., Liu, T.-Y., and Robbins, J. B. 1978. Cell-free biosynthesis of the $O$-acetylated $N$-acetylneuraminic acid capsular polysaccharide of group C Meningococci. J. Bacteriol. 133:1300-1306.

Villalobos, M. A., Nava, N., Vázquez, M., and Quinto, C. 1994. Nucleotide sequence of the Rhizobium etli nodS gene. Gene 150:201202

Weaver, R. W., Wei, G. R., and Berryhill, D. L. 1990. Stability of plasmids in Rhizobium phaseoli during culture. Soil Biol. Biochem. 22: 465-469.

Whitfield, C., and Valvano, M. A. 1993. Biosynthesis and expression of cell-surface polysaccharides in gram-negative bacteria. Adv. Microb. Physiol. 35:135-245.

Wilson, K. J., Hughes, S. G., and Jefferson, R. A. 1992. The Escherichia coli gus operon, induction and expression of the gus operon in E. coli and the occurrence and use of GUS in other bacteria. Pages 7-23 in: GUS Protocols, Using the GUS Gene as a Reporter of Gene Expression. S. R. Gallagher, ed. Academic Press, San Diego, CA. 